\title{
Histopathological indicators: a useful fish health monitoring tool in common carp (Cyprinus carpio Linnaeus, 1758] culture
}

Research Article

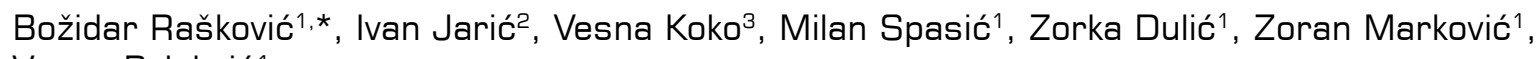
Vesna Poleksić ${ }^{1}$

'University of Belgrade, Faculty of Agriculture, Zemun,

11080 Belgrade, Serbia

2University of Belgrade, Institute for Multidisciplinary Research,

11000 Belgrade, Serbia

3University of Belgrade, Faculty of Biology,

11000 Belgrade, Serbia

Received 11 December 2012; Accepted 20 April 2013

Abstract: In order to evaluate the relationship between water quality in ponds and indices of histopathological changes occurring in the vital organs of the common carp (Cyprinus carpio L., 1758), two six-month field experiments were carried out using two different water supplies: from the nearby stream and a tube well. The fish were fed supplemental feed: raw cereals, pelleted and extruded compound feed. Histopathological analysis, alteration frequencies, and semi-quantitative scoring of the changes were used to assess the health status of the fish. Ponds supplied by stream water were characterized by higher water hardness, dissolved oxygen and pH values, while those supplied by the tube well had higher electroconductivity, total ammonium and orthophosphates content. Fish survival rate and habitat suitability index were lower in ponds supplied by stream water, while the weight gain did not differ between the two water supplies. The use of stream water resulted in a higher level of histopathological changes in gills and liver. Among the water quality parameters, $\mathrm{pH}$ level had the strongest influence on fish. Differences in water supply produced greater influence on the level of histopathological changes than the type of feed applied. Gills were the most sensitive organ, while the kidney was the least responsive.

Keywords: Histopathology • Semi-quantitative scoring • Water quality • Pond • Common carp

(C) Versita Sp. z 0.0 .

\section{Introduction}

The use of histopathological (HP) indicators is a frequent practice in fish health research, as they are able to provide information on chronic and sub-lethal effects of xenobiotics on organs $[1,2]$ and for the assessment of fish stress [3,4]. They are usually applied in research of polluted aquatic ecosystems, since they are good indicators of altered or polluted environments [5-9]. Gills, liver, kidney, and skin are the most frequently used $\mathrm{HP}$ indicators in assessing health status of fish [10].

A variety of stressors are present in the fish pond. Stress can be initiated by inadequate water quality, stocking density, diet or feeding technique, infestation by parasites or a disease [11]. The level of stress in farmed fish is usually assessed using physiological parameters [12], while HP parameters are rarely used, especially in common carp (Cyprinus carpio) reared in earthen ponds [13-16]. Contrary to natural freshwater ecosystems, the water quality in fish ponds is monitored and maintained within certain limits. However, the interaction between different factors can affect the environment, making it less suitable and consequently induce stress in fish [12]. Environmental stress in fish triggers the hypothalamic-pituitary-inter-renal axis, which helps fish to adapt to environmental change [17]. This mechanism causes an increase in ACTH and cortisol, which alter fish metabolism and physiology, and if the stressor is chronic, changes in organ morphology occur [18]. Such changes can be detected by means of histopathology. In addition, by using a scoring system, it is possible to quantify HP changes and correlate them 
with the level of environmental stressors. The aim of the present study was to evaluate the relationship between water quality in ponds and different supplemental feeds with indices of HP changes occurring in vital organs of common carp.

\section{Experimental Procedures}

\subsection{Field study design}

Two six-month field experiments were carried out in 2008 and 2009 (from 29/04/2008 to 26/10/2008 and from 20/04/2009 to 18/10/2009) at the Center for Fishery and Applied Hydrobiology (CEFAH) at the Faculty of Agriculture, University of Belgrade. At the beginning of the growing season, in March, carp yearlings were transported to the CEFAH from the fish farm "St. Nicholas" (Neuzina, Serbia). After a one-month period of adaptation to new ponds, fish were placed in three earthen ponds, each measuring (LxW) 36x25 m, with average water depth of $0.61 \mathrm{~m}$ and each stocked with 400 individuals with an average body mass of $103.6 \pm 26.4 \mathrm{~g}$ (Mean $\pm \mathrm{SD}$ ) in the first and $114.9 \pm 20.7 \mathrm{~g}$ (Mean \pm SD) in the second year of study. A different water supply was used each year: in 2008, water supply was from the nearby stream (SW), while in 2009 water from a tube well (TW), $125 \mathrm{~m}$ deep, was used. The stream is recipient of discharge from surrounding households, which are interspaced throughout the school estate land. In each of the three ponds, fish were fed with feed supplements: raw cereals (CF), pelleted (PF) and extruded (EF) compound feed. Cereals consisted of 1:1:1 ratio mixture of wheat, corn and barley grains. The other two feed types were made of the same components, but prepared using different treatments: one by steam pelleting and the other by an extruding process. Feed chemical composition is presented in Table 1. Feed was produced by the company "Veterinarski Zavod" (Subotica, Serbia). Once every 15 days, a sample of 50 fish from each pond was measured and their body mass was used as a correction to feeding rates. The daily feeding rate was up to $3 \%$ of total fish body mass, although the percentage was lowered if environmental conditions were unfavourable. Fish were not fed on sampling days, or when uneaten feed was found in the ponds. Water temperature, $\mathrm{pH}$ level, dissolved oxygen (DO), transparency and electroconductivity (EC) were monitored daily at 12 noon, using a Multi 340i water field kit (WTW, Germany). Water hardness, chemical oxygen demand through redox titrometry $\left(\mathrm{KMnO}_{4}\right)$ (COD), total ammonia-nitrogen (TAN), nitrates, total nitrogen, orthophosphates, and total phosphates were measured once each 15 days, at the time when fish were sampled.
The latter parameters were analysed by the Institute for Public Health "Milan Jovanović-Batut" (Belgrade, Serbia). Concentrations of unionized ammonia-nitrogen (UAN) were determined using table values [19].

Weight gain and survival rate were calculated using the following equations: Weight gain (WG) = final body mass (g) - initial body mass (g); Survival rate $(S R)=\left(N_{t} / N_{o}\right) \times 100 ; N_{t}$ - number of fish in the pond at the end of the field study, $N_{0}$ - number of fish in the pond at the start of the field study. Habitat suitability index $(\mathrm{HSI})$ was calculated using the following equation: $\mathrm{HSI}=\left[2 \times\left(\mathrm{V}_{7}\right)^{1 / 2}+2 \mathrm{~V}_{12}+\mathrm{V}_{14}\right] / 6 ; \mathrm{V}_{7}-$ maximum midsummer water temperature in the pond; $V_{12}$ - minimum dissolved oxygen levels during midsummer; $\mathrm{V}_{14}-\mathrm{pH}$ levels during the year. This represents a modified equation for the water quality assessment of a lacustrine common carp habitat, established by Edwards and Twomey [20].

\subsection{Histological analysis}

From each of the ponds, three fish were sampled each 2.2 month and five at the end of experiment: a total of 20 fish per pond. Fish were anaesthetized with benzocaine and sacrificed with a quick blow to the head. Liver, kidney and gill samples were transferred to $4 \%$ formaldehyde (Lach-Ner, Czech Republic). Following the fixation in formaldehyde, tissues were placed in an automatic tissue processor Leica TP 1020 (Leica, Austria) and dehydrated in ethanol series, treated with xylene and embedded in paraffin. Paraffin blocks were serially sectioned at $5 \mu \mathrm{m}$ thickness on a microtome Leica SM 2000R (Leica, Austria); sections were dewaxed and stained with haematoxylin and eosin (HE) or Periodic acid-Schiff (PAS) [21]. Microphotographs were

\begin{tabular}{c|ccc}
\hline & \multicolumn{3}{|c}{ Feed } \\
Component & EF & PF & CF \\
\hline \hline Crude proteins & 26.5 & 28.5 & 11.3 \\
Lipids & 7.8 & 8.0 & 3.3 \\
Crude fibers & 3.5 & 3.3 & 7.4 \\
Moisture & 9.4 & 12.0 & 9.8 \\
Ash & 4.7 & 4.7 & 1.9 \\
${ }^{1}$ Nitrogen-Free Extract (NFE) & 57.5 & 55.5 & 76.1 \\
${ }^{2}$ Gross energy (kJ /g) & 17.5 & 18.0 & 15.7 \\
${ }^{3}$ P/E ratio & 15.1 & 15.8 & 7.2 \\
\hline
\end{tabular}

Table 1. Chemical composition of feed used in the field study (\%).

${ }^{1}$ Nitrogen free extract + fibre, (NFE) $=100-(\%$ protein $+\%$ lipid + \% ash + \% crude fibers);

${ }^{2}$ Calculated by: Crude protein $=23.9 \mathrm{~kJ} / \mathrm{g}$, Crude lipids $=39.8 \mathrm{~kJ} / \mathrm{g}, N F E=17.6 \mathrm{~kJ} / \mathrm{g}$;

${ }^{3} P / E=$ Protein to energy ratio in $g$ protein $(\mathrm{kJ}) /$ gross energy. 
taken by a Leica DM LS microscope (Leica, Austria) equipped with a Leica DC 300 camera.

\subsection{Semi-quantitative scoring system}

A scoring system proposed by Bernet et al. [10] was applied for the assessment of pathological changes in fish that were caused by different degrees of pollution. According to this method, pathological changes are classified into five reaction patterns, namely: circulatory, regressive, progressive, inflammatory and neoplastic. An importance factor ranging from 1 (minimal alteration) to 3 (marked importance) is assigned to each alteration, determining the relevance of a lesion and its pathological importance. Depending on the degree and extent of lesions, a score value ranging from 0 (unchanged) to 6 (severe occurrence) is determined. By using the importance factor and the score value, an organ index is obtained. The method was used for estimating HP index in three organs: gills (IG), liver (IL) and kidney (IK) The total index (IT) was calculated as a sum of all three organ indices.

\subsection{Statistical analysis}

Comparisons of water quality parameters and histopathology between ponds were performed by the non-parametric Kruskal-Wallis test, since variables did not meet the normality assumption. Two different water supplies were compared using the Mann-Whitney $U$ test. Spearman's non-parametric correlation test was used at a 95\% confidence limit to assess the relationship between water quality parameters and HP indices. To assess the differentiation among the fish fed three different feeds and two different water supplies, based on the level of histopathological changes in each of the three assessed tissues, groups were compared by means of Canonical Discriminant
Analysis. The scores for each specific pathological change in each of the tissues were used as the input variables.

\section{Results}

\subsection{Differences among the three feed types}

In terms of water quality, there were minor differences among the three ponds in both study years. In 2008 (SW), two parameters differed significantly $(\mathrm{P}<0.05)$ among lakes: electroconductivity (CF: 959.2 \pm 99.2 , PF: $1044.9 \pm 75.0$, EF: $949.7 \pm 77.1)$ and transparency (CF: $14.14 \pm 3.05$, PF: $16.33 \pm 3.22$, EF: 14.14 \pm 3.52 ). The only parameter that differed significantly in 2009 (TW) was the $\mathrm{pH}$ level (CF: $9.07 \pm 0.16$, PF: $8.96 \pm 0.13$, EF: $8.93 \pm 0.12)$. Histological alterations showed no differences among ponds in either of the tissue indices (Figure 1).

\subsection{Differences between the two water supplies}

Survival rate and $\mathrm{HSI}$ of fish reared in ponds supplied by stream water were both lower than in those supplied by water from a tube well, while fish weight gain did not differ significantly between the two groups (Table 2). Fish survival rate in ponds supplied by stream water was low $(59 \%)$, compared to ponds supplied by tube water (88\%). HSI values for all ponds were low (the maximum possible $\mathrm{HSI}$ value is 1 ), especially in ponds with stream water (0.040).

Ponds supplied by stream water had significantly higher water hardness, DO and $\mathrm{pH}$ level, while those supplied by water from a tube well had a significantly higher electroconductivity, total ammonium and orthophosphates. There were no differences between the two groups in other water quality parameters (Table 3). Variation in the majority of parameters was

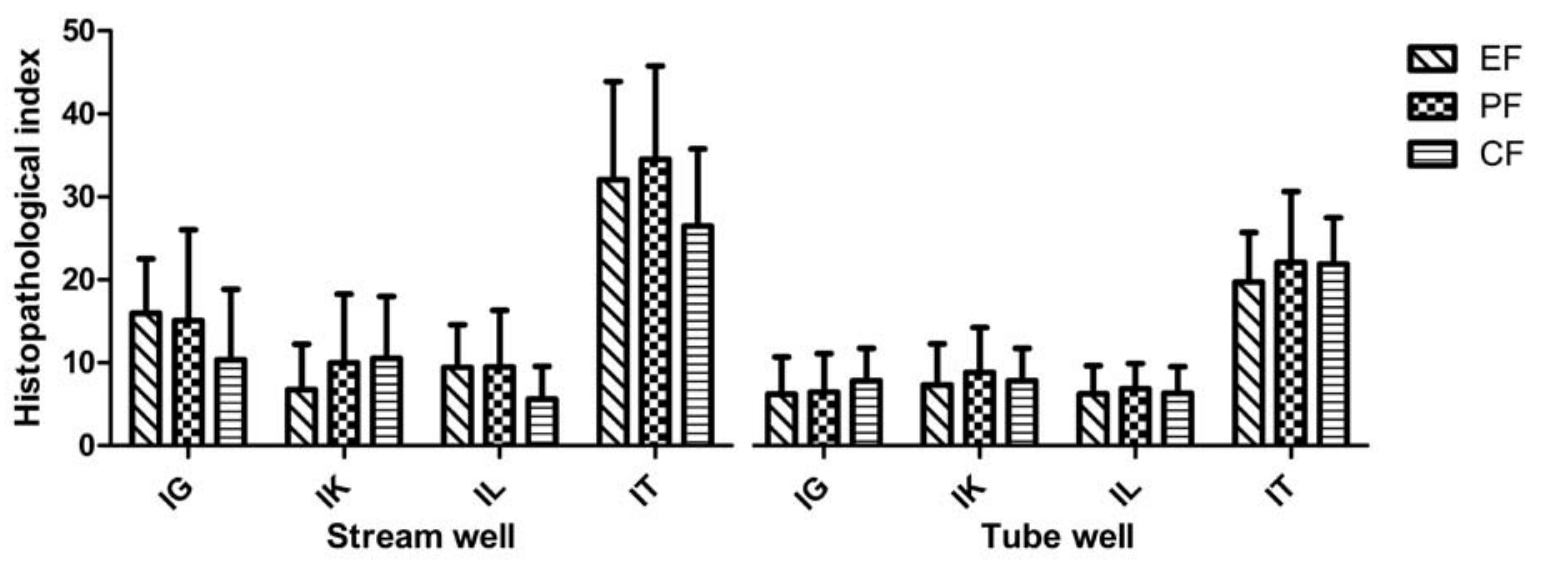

Figure 1. Histopathological index per fish group; data are presented as mean values \pm SD; EF - extruded feed, PF - pelleted feed, CF - cereals, IG - gill histopathology index, IK - kidney histopathology index, IL - liver histopathology index, IT - total index. 


\begin{tabular}{c|ccc}
\hline \multirow{2}{*}{ Parameter } & \multicolumn{2}{|c}{ Water supply } & P-value \\
\hline \hline Weight gain (g) & Stream water & Tube well & 0.167 \\
Survival rate (\%) & $683.2 \pm 68.0$ & $505.4 \pm 169.3$ & 0.000 \\
Habitat suitability index & $59.16 \pm 4.69^{*}$ & $87.76 \pm 2.80^{*}$ & 0.006 \\
\hline
\end{tabular}

Table 2. Weight gain, survival rate and habitat suitability index of the common carp in ponds with two different water supplies.

* parameter differed significantly between the two groups (Mann-Whitney $U$ test, $P<0.05$ )

\begin{tabular}{|c|c|c|c|c|c|}
\hline \multirow{3}{*}{ Parameter } & \multicolumn{4}{|c|}{ Water supply } & \multirow{3}{*}{ P-value } \\
\hline & \multicolumn{2}{|c|}{ Stream water } & \multicolumn{2}{|c|}{ Tube well } & \\
\hline & Mean \pm SD & Interval & Mean \pm SD & Interval & \\
\hline Temperature $\left({ }^{\circ} \mathrm{C}\right)$ & $23.9 \pm 4.6$ & $12.4-34.4$ & $22.8 \pm 2.3$ & $16.3-30.3$ & 0.394 \\
\hline Transparency (m) & $0.15 \pm 0.02$ & $0.02-0.27$ & $0.16 \pm 0.03$ & $0.06-0.20$ & 0.187 \\
\hline $\mathrm{EC}(\mu \mathrm{S} / \mathrm{cm})$ & $987.0 \pm 71.6^{\star}$ & $728.0-1414.0$ & $2051.1 \pm 107.9^{*}$ & $1801.0-2260.0$ & 0.000 \\
\hline $\mathrm{DO}(\mathrm{mg} / \mathrm{L})$ & $11.00 \pm 2.97^{\star}$ & $0.70-33.70$ & $3.99 \pm 0.91^{*}$ & $1.00-13.00$ & 0.000 \\
\hline $\mathrm{pH}$ & $9.63 \pm 0.54^{\star}$ & $7.57-10.93$ & $9.00 \pm 0.11^{*}$ & $8.75-9.47$ & 0.000 \\
\hline Nitrates (mg/L) & $3.42 \pm 1.89$ & $0.60-11.00$ & $4.97 \pm 2.47$ & $2.10-10.50$ & 0.082 \\
\hline $\mathrm{COD}(\mathrm{mg} / \mathrm{L})$ & $17.97 \pm 8.44$ & $1.80-30.50$ & $18.28 \pm 2.98$ & $5.25-28.85$ & 0.858 \\
\hline Water hardness $(\mathrm{dH})$ & $21.13 \pm 2.14^{\star}$ & $15.10-21.00$ & $5.07 \pm 2.14^{*}$ & $2.46-14.04$ & 0.000 \\
\hline Orthophosphates (mg/L) & $0.043 \pm 0.046^{*}$ & $0.001-0.309$ & $0.224 \pm 0.091^{*}$ & $0.093-0.487$ & 0.000 \\
\hline Total phosphates (mg/L) & $0.387 \pm 0.118$ & $0.019-0.970$ & $0.619 \pm 0.637$ & $0.086-1.700$ & 0.141 \\
\hline TAN (mg/L) & $0.13 \pm 0.07^{\star}$ & $0.01-0.47$ & $0.34 \pm 0.24^{\star}$ & $0.01-0.90$ & 0.001 \\
\hline UAN (mg/L) & $0.11 \pm 0.08$ & $0.01-0.32$ & $0.11 \pm 0.08$ & $0.01-0.27$ & 0.916 \\
\hline Total nitrogen (mg/L) & $3.38 \pm 1.20$ & $1.10-5.76$ & $2.55 \pm 1.34$ & $0.50-4.31$ & 0.182 \\
\hline
\end{tabular}

Table 3. Values of water quality parameters (mean values \pm SD and ranges) in ponds with two different water supply; TAN - total ammonia, UAN - unionized ammonia, EC - electroconductivity, DO - dissolved oxygen, COD - chemical oxygen demand.

* parameter differed significantly between the two groups (Mann-Whitney $U$ test, $P<0.05$ )

higher in ponds with stream water, reaching extreme values in certain periods, such as those for water temperature $\left(34.4^{\circ} \mathrm{C}\right)$, $\mathrm{pH}$ level $(10.93)$ and $\mathrm{DO}$ value $(0.7 \mathrm{mg} / \mathrm{L})$.

$\mathrm{HP}$ indices differed significantly between the ponds with different water supplies (Figure 2). Fish from ponds supplied with stream water had a higher total $(P<0.001)$, gills $(P<0.001)$ and liver $(P<0.01)$ HP index, while kidney HP index did not differ between the two groups $(P=0.860)$.

The most frequent gill alterations observed during this study were hyperaemia, hyperplasia (Figure $3 \mathrm{~A}$ ) and the lifting of epithelium (Table 4). In fish from ponds with stream water, a higher frequency of hyperplasia $(P<0.05)$ and the lifting of epithelium $(P<0.05)$ were observed. Irreversible alterations: complete lamellar

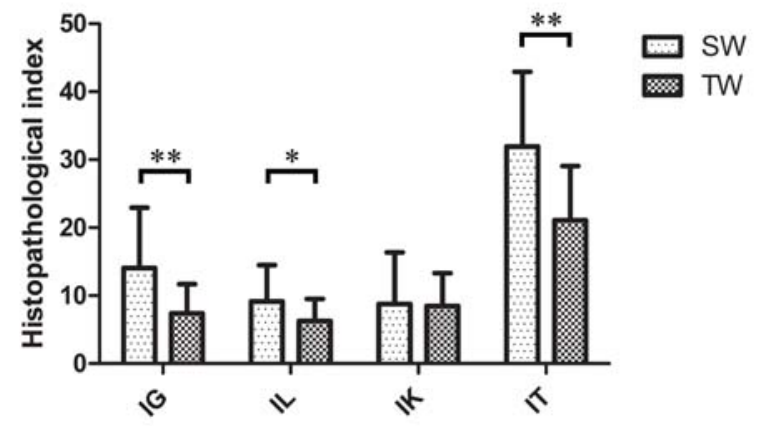

Figure 2. Histopathological index between the ponds with two different water supply; data are presented as mean values $\pm \mathrm{SD} ; \mathrm{IG}$ - gill histopathology index, IK - kidney histopathology index, IL - liver histopathology index, IT total index, SW - stream water, TW - tube well; Statistical significance level: ${ }^{\star} P<0.01,{ }^{\star} * P<0.001$. 

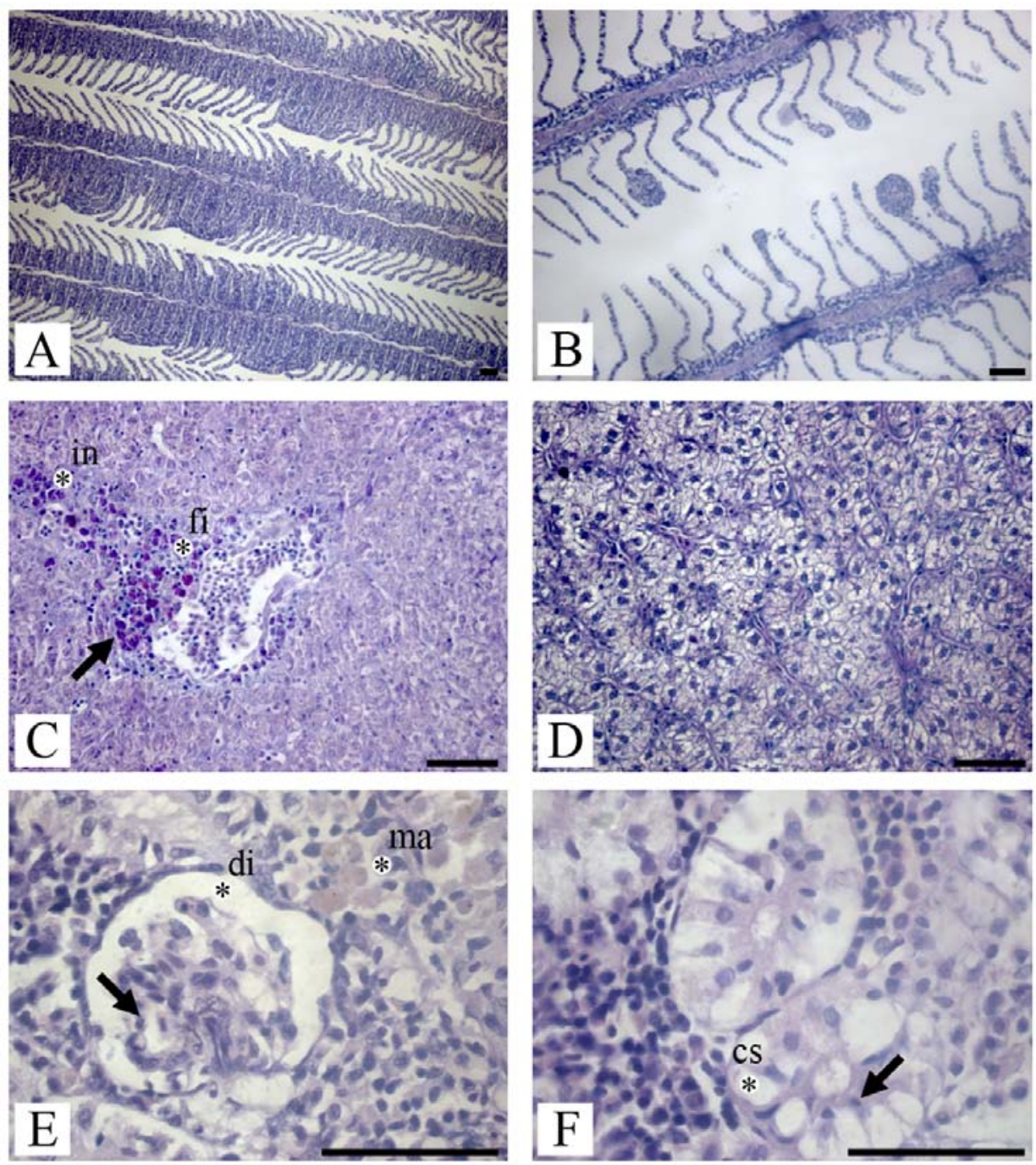

Figure 3. Histopathological alterations found in the study: A. Gills: hyperplasia of the branchial epithelium (HE x10); B. Gills: aneurism of terminal capillaries (HE x20); C. Liver: arrow = presence of EGC, $\mathrm{fi}=$ fibrosis, in = leukocyte infiltration (PAS x40); D. Liver: sinusoidal capillaries congestion (HE x40); E. Kidney: arrow = dilation of glomerular capillary, di = dilation of the Bowman's space, $\mathrm{ma}=$ macrophage aggregates (HE x100); F. Kidney: note decrease of tubular lumen, arrow = pyknotic nucleus, cs = cloudy swelling (HE x100); bar = $50 \mu \mathrm{m}$.

fusions and necrosis $(P<0.05)$ of the branchial epithelium were present in fish from ponds with stream water, but not in those from ponds with water from the tube well. However, a higher presence of circulatory changes, such as hyperaemia $(P<0.05)$, aneurism (Figure 3B; $\mathrm{P}<0.05)$ and stasis, was recorded in fish from ponds with tube well water.

Tissue pathologies in blood vessels and circulatory changes in liver were higher than those in gills. The most common alterations included fibrosis (Figure $3 \mathrm{C}$ ) and the congestion of blood vessels (Figure 3D), as well as the presence of eosinophilic granular cells (EGC). Fibrosis and the congestion of blood vessels were both more frequent in fish from ponds with stream water
$(P<0.05)$. Other alterations were minor and there were no differences between the groups, with the exception of leukocyte infiltration, which was more frequent in fish from ponds with tube well water. Alterations in the kidney did not differ between the two groups. The dilation of glomerular capillaries was the only lesion that differed between the two groups (Figure 3E; $\mathrm{P}<0.05$ ), and the occurrence of this alteration was high, particularly in ponds with stream water. Two lesions had a high HP index in kidneys as well: dilation of Bowman's space (Figure $3 \mathrm{E}$ ) and tubular cloudy swelling (Figure 3F). Regenerating nephrons were also noticed in experimental fish, but their occurrence was not different between years. 


\begin{tabular}{|c|c|c|c|}
\hline \multirow{2}{*}{ Histopathological change } & \multicolumn{2}{|c|}{ Water supply } & \multirow[b]{2}{*}{ P-value } \\
\hline & Stream water & Tube well & \\
\hline \multicolumn{4}{|l|}{ Gills } \\
\hline Epithelial lifting & $1.74 \pm 1.57^{\star}$ & $0.33 \pm 0.55^{\star}$ & 0.000 \\
\hline Hyperplasia of epithelium & $1.23 \pm 1.58^{\star}$ & $0.24 \pm 0.48^{*}$ & 0.005 \\
\hline Hyperemia & $1.15 \pm 1.48^{\star}$ & $1.63 \pm 1.23^{\star}$ & 0.045 \\
\hline Stasis & $0.48 \pm 1.15$ & $0.72 \pm 1.28$ & 0.159 \\
\hline Aneurism & $0.14 \pm 0.38^{\star}$ & $0.63 \pm 1.23^{\star}$ & 0.020 \\
\hline Complete lamellar fusions & $0.03 \pm 0.12$ & $0.00 \pm 0.00$ & 0.070 \\
\hline Necrosis & $0.09 \pm 0.23^{\star}$ & $0.00 \pm 0.00^{\star}$ & 0.008 \\
\hline \multicolumn{4}{|l|}{ Liver } \\
\hline Fibrosis of blood vessels & $1.93 \pm 1.49^{\star}$ & $1.12 \pm 1.05^{\star}$ & 0.013 \\
\hline Congestion of blood vessels & $2.53 \pm 1.31^{*}$ & $1.02 \pm 1.05^{\star}$ & 0.000 \\
\hline Presence of EGC & $1.67 \pm 1.21$ & $1.33 \pm 1.08$ & 0.296 \\
\hline Macrophage aggregates & $0.00 \pm 0.00$ & $0.02 \pm 0.09$ & 0.231 \\
\hline Leukocytes infiltration & $0.22 \pm 0.74^{\star}$ & $0.32 \pm 0.58^{\star}$ & 0.034 \\
\hline Stasis & $0.16 \pm 0.82$ & $0.11 \pm 0.40$ & 0.395 \\
\hline Cloudy swelling & $0.09 \pm 0.53$ & $0.00 \pm 0.00$ & 0.253 \\
\hline Necrosis & $0.18 \pm 0.48$ & $0.12 \pm 0.40$ & 0.296 \\
\hline \multicolumn{4}{|l|}{ Kidney } \\
\hline Dilation of Bowman's space & $1.94 \pm 1.78$ & $1.54 \pm 1.64$ & 0.264 \\
\hline Increased Bowman's capsule thickness & $0.10 \pm 0.34$ & $0.03 \pm 0.10$ & 0.500 \\
\hline Dilation of glomerular capillaries & $1.22 \pm 1.38^{\star}$ & $0.54 \pm 0.97^{\star}$ & 0.006 \\
\hline Tubular cloudy swelling & $1.36 \pm 1.32$ & $1.93 \pm 1.48$ & 0.103 \\
\hline Decrease of the tubular lumen & $0.33 \pm 0.73$ & $0.58 \pm 1.03$ & 0.234 \\
\hline Macrophage aggregates & $0.53 \pm 0.56$ & $0.64 \pm 0.63$ & 0.496 \\
\hline Stasis & $0.48 \pm 1.12$ & $0.63 \pm 1.18$ & 0.276 \\
\hline Fibrosis of blood vessels & $0.17 \pm 0.57$ & $0.15 \pm 0.47$ & 0.844 \\
\hline Regenerating nephrons & $0.25 \pm 0.55$ & $0.15 \pm 0.23$ & 0.776 \\
\hline Necrosis & $0.51 \pm 0.38$ & $0.48 \pm 0.57$ & 0.208 \\
\hline
\end{tabular}

Table 4. The frequency of the most important histopathological lesions found in the study; scores are presented as mean values \pm SD; tissue alterations were scored as follows: $0=$ none, $1=$ mild, $3=$ moderate and $5=$ severe.

* parameter differed significantly between the two groups (Mann-Whitney $U$ test, $P<0.05$ )

\subsection{Canonical Discriminant Analysis}

The Canonical Discriminant Analysis suggested a moderate differentiation among the six compared groups (Figure 4). As can be observed in the Figure, there was a stronger differentiation based on the type of water supply applied, than on the type of feed. Moreover, histopathological changes in fish from ponds with tube well water were on average more uniform than those in fish from ponds with stream water. Two canonical functions (CV) together accounted for $64.5 \%$ of the total heterogeneity (CV1 - 33.4\% and CV2 - 31.1\%). Fish from ponds with stream water were separated from those with tube well water along the first canonical function, mostly by congestions of blood vessels in liver, lifting of epithelium and local proliferations in gills, as well as by dilation of glomerular capillaries in kidneys and liver fibrosis. There was only a low differentiation of groups along the second canonical function, mostly by the fusion of the tips of primary lamellae and oedema in gills, as well as by glomerular necrosis in kidneys.

\subsection{Correlations}

Correlation between HP indices and water quality parameters are presented in Table 5. There was a positive correlation between the HP index of gills and the total index and EC, $\mathrm{pH}$ and COD levels $(\mathrm{P}<0.05)$. The liver histopathology index was positively correlated with $\mathrm{pH}$ level $(\mathrm{P}<0.05)$. 


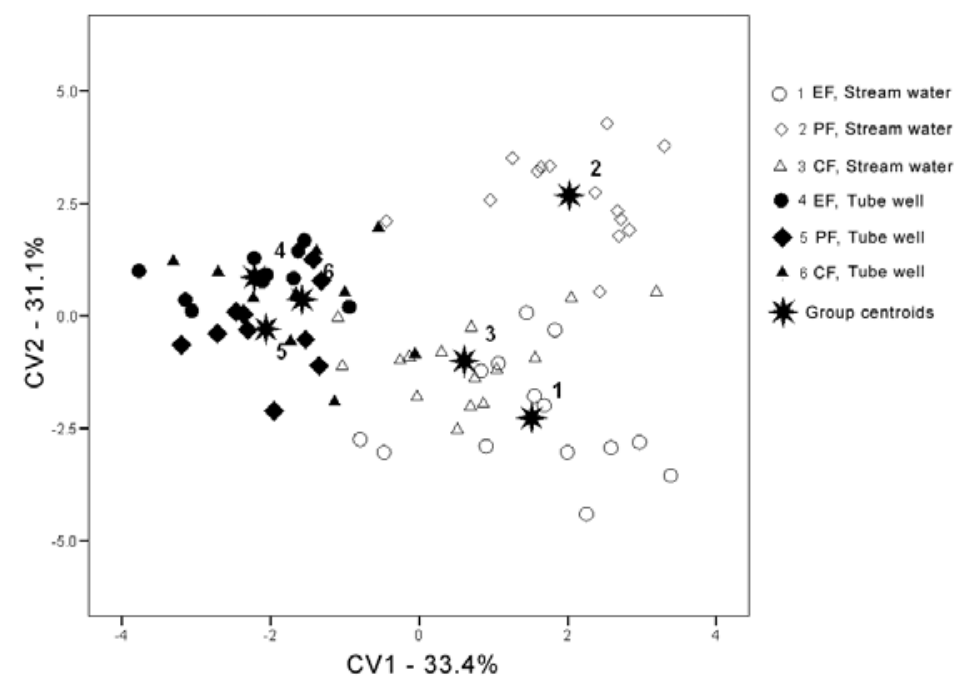

Figure 4. Canonical Discriminant Analysis applied on the histopathological changes in common carp with three different feeds and two different water supplies applied; the input variables are the scores for each specific pathological change in each of the three assessed tissues; CF - cereals; PF - pelleted feed; EF - extruded compound feed.

\section{Discussion}

Influence of the protein level in supplemented feed on water quality in fish ponds is documented in the literature [22]. It is estimated that $87.9 \%$ of the nitrogen input to ponds is accounted to feed [23], and supplemental feed can indirectly influence fish health [24]. Even though two commercial feeds in the present study had a higher protein level than cereals, there were no differences observed among the three ponds with regard to the water quality. The probable reason was that the amount of nitrogen in the water was proportional to the carp biomass $[25,26]$.

Common carp has a broad ecological spectrum and can tolerate extreme environmental conditions. Nevertheless, fish loss is often recorded in semiintensive aquaculture, and is estimated at $20-40 \%$ during rearing season [27]. Fish survival in ponds supplied by water from the tube well was higher than that in ponds with stream water. This loss was partly influenced by a reduced water quality, directly or indirectly by higher $\mathrm{pH}$ level, which is reported to reduce fish growth and survival rate at values close to 10.3 [28]. Moreover, other parameters, such as temperature, DO, COD, TAN and UAN, were also frequently outside optimal levels for carp production, as suggested by Boyd [29]. These factors affected vital organs, resulting in HP changes.

Salinity in ponds with tube well water (measured through EC) was well above values appropriate for freshwater, classifying it as sub-saline water. Common carp is moderately tolerant to salinity. Low levels of

\begin{tabular}{c|cccc}
\hline & $\mathrm{IG}$ & $\mathrm{IL}$ & $\mathrm{IK}$ & $\mathrm{IT}$ \\
\hline \hline TAN & -0.19 & -0.02 & -0.27 & -0.30 \\
UAN & 0.03 & -0.02 & -0.09 & -0.03 \\
Nitrates & -0.03 & 0.08 & -0.10 & -0.06 \\
EC & $0.46^{\star}$ & 0.24 & 0.17 & $0.53^{\star}$ \\
PH & $0.51^{\star}$ & $0.34^{\star}$ & 0.15 & $0.60^{\star}$ \\
DO & 0.28 & 0.15 & 0.04 & 0.22 \\
COD & $0.33^{\star}$ & 0.03 & 0.10 & $0.33^{\star}$ \\
\hline
\end{tabular}

Table 5. Correlation matrix of histopathological indices and water quality parameters; TAN - total ammonia; UAN - unionized ammonia; EC - electroconductivity; DO - dissolved oxygen; COD - chemical oxygen demand; IG - gill histopathology index; IK - kidney histopathology index; IL - liver histopathology index; IT - total index.

*parameters were significantly correlated (Spearman's correlation test, $P<0.05$ )

salinity, such as those measured in ponds with stream water, are usually well tolerated and in some trials even result in weight gain improvement [30]. Common carp is often reared in sub-saline conditions [31]. Higher values, however, such as those detected in ponds with tube well water, are able to affect fish metabolism [32], causing physiological changes and reduced growth [33], although increased mortality was not reported. Besides salinity, carp is also tolerant to low levels of DO and can survive for more than 7 days in the water with $0.5 \mathrm{mg} / \mathrm{L}$ of DO [34]. COD levels were high, as compared to natural freshwater, but these levels are 
tolerated in semi-intensive aquaculture and are related to the quantity of supplemented feed [27]. According to the available literature [35], COD levels are correlated with TAN values. Several studies have documented a relationship between water temperatures and the toxicity of different compounds in aquatic environments, including ammonium [19,36-38].

Mean UAN values in the present study were $0.11 \mathrm{mg} / \mathrm{L}$. Such levels either did not cause histopathological changes in laboratory experiments $[39,40]$, or the changes were only mild [41]. However, the problem is increased ammonia toxicity, when the water $\mathrm{pH}$ level is elevated [40]. Therefore, we assume that the $\mathrm{pH}$ level had the most important, but indirect effect on histopathology of the gills in this study. In alkaline waters, such as those in ponds supplied by stream water, fish have difficulties with ammonia excretion [42-44]. Even low UAN levels could endanger fish health when $\mathrm{pH}$ levels are elevated, due to high ammonia content in blood plasma [45]. This is supported by the fact that fish gill tissue was not affected during the exposure to extreme $\mathrm{pH}$ levels (10) when ammonium was not present in the water [40]. A positive correlation between TAN or UAN and HP changes in gills has been established in the literature $[40,41,46]$, however this was not the case in the present study. Instead, a positive correlation was established between HP indices and $\mathrm{pH}, \mathrm{COD}$ and $\mathrm{EC}$. The potential interaction among these factors could produce a suitable environment for increased UAN toxicity [38], especially in the case of high temperature and $\mathrm{pH}$ levels, and low $\mathrm{DO}$ values $[19,47]$, as was recorded in ponds with stream water. This was confirmed by $\mathrm{HSI}$ values being lower in all ponds with stream water. Such extreme conditions are able to cause histopathological changes and while the recovery is possible, it is often slow and will last only until water quality deteriorates again [48,49]. Other parameters, namely nitrate levels, orthophosphates and total phosphates, total nitrogen, water hardness and transparency were within optimal ranges for fish rearing [29].

Alterations observed in the assessed vital organs were mostly mild and reversible [10]. Necrosis and complete lamellar fusion found in the gills are characterized as severe changes [50]. Necrosis is an irreversible change, but its frequency in the present study was low and necrotic changes were focal. The exception was in the kidneys, with a higher frequency of necrosis than in the other tissues, although there was no difference between the two water supplies.

The most frequent HP alterations in all organs in the present study were circulatory changes. To cope with a low DO level in ponds with tube well water and extreme
$\mathrm{pH}$ and temperature values in ponds with stream water, carp had to adapt the gill surface to pond conditions [51]. Hyperplasia and lifting of epithelium are the most common alterations found in gill histopathology studies [52]. These changes represent the fastest and easiest adaptations to low water quality, with the purpose of decreasing the respiratory surface and increasing diffusion distance [47]. On the other hand, blood flow in fish gills is much higher during hypoxia or reduced oxygen level, which might explain the higher value of gill circulatory changes in fish from ponds with tube well water [53].Unlike gills, the liver is protected from physical exposure to the external environment [18]. Moreover, since xenobiotics were not present in fish ponds, hepatocyte alterations were rare, with a low frequency of cloudy swelling and macrophage aggregates confirming these findings. However, in contrast to the gills, the most common liver lesions were vascular changes. These are frequently reported in fish exposed to organic contaminants [54], while Koponen et al. [55] concluded that the appearance of fibrosis in portal and periportal areas is due to seasonal changes. EGC are often found in connective tissue or in the blood vessels and their presence could indicate response to inflammation [56].

The histopathology of the kidneys did not show sensitivity to the water quality parameters. A number of alterations were observed on both glomerular and tubular tissues. A majority of alterations of nephrons and tubules observed are considered mild and commonly found on freshwater reference sites [57]. The only moderate change was a decrease of the tubular lumen [6], but this lesion had a low frequency in the present study. A presence of regenerative tubules and glomeruli is observed in healthy and young fish [58] and represents evidence of good fish health status.

\section{Conclusions}

To conclude, the results obtained in the present study have demonstrated that histopathology represents a useful indicator of the water quality in fish ponds where a semi-intensive culture system is practiced. Gills were the most sensitive organ, while the kidney was the least responsive. The majority of HP alterations were mild and reversible.

Despite this, the level of mortality that occurred in ponds with stream water was obviously a consequence of deteriorated water quality, which also induced histological changes. The results of the study indicate that, among the observed water parameters in the fish pond, a crucial role is played by the $\mathrm{pH}$ level. In the present study, water quality in ponds with tube well 
water was worse than in those with stream water, but the $\mathrm{pH}$ level was the limiting factor. Although tube well water used had a high salinity, ammonia and low DO levels, vital organ histopathology was not markedly affected. While the average values of water quality parameters were more favorable in ponds with stream water, occasional extreme values of certain parameters caused lower HP indices. Finally, the study confirmed that HP changes are not stressor-specific, they rather indicate all possible interactions among the factors (additive, synergistic, or/and antagonistic). In addition, scoring of HP changes offers an accurate measure of the level of environmental stress.

\section{Acknowledgements}

The study was supported by a project of the Ministry of Education, Science and Technological Development of the Republic of Serbia (project No. TR31075). We wish to thank our technician, Mrs. Zorica Radović for her excellent work in preparing histological samples.

\section{References}

[1] Hinton D.E., Lauren D.J., Integrative histopathological approaches to detecting effects of environmental stressors on fishes, In: Adams R., Lloyd R. (Eds.), Biological indicators of stress in fish, American Fisheries Society, Bethesda, Maryland, 1990

[2] van der Oost R., Beyer J., Vermeulen N.P.E., Fish bioaccumulation and biomarkers in environmental risk assessment: a review, Environ. Toxicol. Pharmacol., 2003, 13, 57-149

[3] Schwaiger J., Wanke R., Adam S., Pawert M., Honnen W., Triebskorn R., The use of histopathological indicators to evaluate contaminant-related stress in fish, J. Aquat. Ecosyst. Stress Recovery, 1997, 6, 75-86

[4] Teh S.J., Adams S.M., Hinton D.E., Histopathologic biomarkers in feral freshwater fish populations exposed to different types of contaminant stress, Aquat. Toxicol., 1997, 37, 51-70

[5] Bernet D., Schmidt-Posthaus H., Wahli T., Burkhardt-Holm P., Evaluation of two monitoring approaches to assess effects of waste water disposal on histological alterations in fish, Hydrobiologia, 2004, 524, 53-66

[6] Camargo M.M.P., Martinez C.B.R., Histopathology of gills, kidney and liver of a Neotropical fish caged in an urban stream, Neotrop. Ichthyol., 2007, 5, 327-336

[7] Carbis C.R., Rawlin G.T., Grant P., Mitchell G.F., Anderson J.W., McCauley I., A study of feral carp, Cyprinus carpio L., exposed to Microcystis aeruginosa at Lake Mokoan, Australia, and possible implications for fish health, J. Fish Dis., 1997, 20, 81-91

[8] Dulić Z., Poleksić V., Rašković B., Lakić N., Marković Z., Živić I., et al., Assessment of the water quality of aquatic resources using biological methods, Desalin. Water Treat., 2009, 11, 264-274
[9] Madureira T.V., Rocha M.J., Cruzeiro C., Rodrigues I., Monteiro R.A.F., Rocha E., The toxicity potential of pharmaceuticals found in the Douro River estuary (Portugal): Evaluation of impacts on fish liver, by histopathology, stereology, vitellogenin and CYP1A immunohistochemistry, after sub-acute exposures of the zebrafish model, Environ. Toxicol. Pharmacol., 2012, 34, 34-45

[10] Bernet D., Schmidt H., Meier W., Burkhardt-Holm P., Wahli T., Histopathology in fish: proposal for a protocol to assess aquatic pollution, J. Fish Dis., 1999, 22, 25-34

[11] Ashley P.J., Fish welfare: Current issues in aquaculture, Appl. Anim. Behav. Sci., 2007, 104, 199-235

[12] Segner H., Sundh H., Buchmann K., Douxfils J., Sundell K.S., Mathieu C., et al., Health of farmed fish: its relation to fish welfare and its utility as welfare indicator, Fish Physiol. Biochem., 2012, 38, 85-105

[13] Rašković B., Poleksić V., Živić I., Spasić M., Histology of carp (Cyprinus carpio, L.) gills and pond water quality in semiintensive production, Bulg. J. Agric. Sci., 2010, 16, 253-262

[14] Skorić S., Rašković B., Poleksić V., Gačić Z., Lenhardt M., Scoring of the extent and intensity of carp (Cyprinus carpio) skin changes made by cormorants (Phalacrocorax carbo sinensis): relationship between morphometric and histological indices, Aquac. Int., 2012, 20, 525-535

[15] Poleksić V., Vlahović M., Mitrović-Tutundžić V., Marković Z., Effects of environmental conditions on gill morphology of carp from the 'Dubica' farm during the 1998 rearing season, Acta Biol. lugosl. (E Ichthyol.), 1999, 31, 43-52

[16] Poleksić V., Dulić-Stojanović Z., Marković Z., Gill structure of carp fingerlings from Baranda fish farm, Acta Biol. Iugosl. (E Ichthyol.), 2002, 34, 11-22 
[17] Mommsen T., Vijayan M., Moon T., Cortisol in teleosts: dynamics, mechanisms of action, and metabolic regulation, Rev. Fish Biol. Fish., 1999, 9, 211-268

[18] Harper C., Wolf J.C., Morphologic effects of the stress response in fish, ILAR J., 2009, 50, 387-396

[19] Svobodová Z., Lloyd R., Máchová J., Vykusová B., Water quality and fish health, Food and Agriculture Organization of the United Nations, Rome, 1993

[20] Edwards E.A., Twomey K., Habitat suitability index models: common carp, U.S. Fish and Wildlife Service, Washington, DC, 1982

[21] Humason G.L., Animal tissue techniques, 3rd, W. H. Freeman, San Francisco, 1979

[22] Bechara J.A., Roux J.P., Ruiz Díaz F.J., Flores Quintana C.I., Longoni de Meabe C.A., The effect of dietary protein level on pond water quality and feed utilization efficiency of pacú Piaractus mesopotamicus (Holmberg, 1887), Aquac. Res., 2005, 36, 546-553

[23] Gross A., Boyd C.E., Wood C.W., Nitrogen transformations and balance in channel catfish ponds, Aquac. Eng., 2000, 24, 1-14

[24] Kaushik S.J., Nutrient requirements, supply and utilization in the context of carp culture, Aquaculture, 1995, 129, 225-241

[25] Driver P.D., Closs G.P., Koen T., The effects of size and density of carp (Cyprinus carpio L.) on water quality in an experimental pond, Arch. Hydrobiol., 2005, 163, 117-131

[26] Lougheed V.L., Crosbie B., Chow-Fraser P., Predictions on the effect of common carp (Cyprinus carpio) exclusion on water quality, zooplankton, and submergent macrophytes in a Great Lakes wetland, Can. J. Fish. Aquat. Sci., 1998, 55, 1189-1197

[27] Marković Z., Common carp: rearing in fish ponds and cages [Šaran: gajenje u ribnjacima i kaveznim sistemima], Prof. dr Zoran Marković, Belgrade, 2010, (in Serbian)

[28] Korwin-Kossakowski M., Growth and survival of carp (Cyprinus carpio L.) larvae in alkaline water, J. Fish Biol., 1992, 40, 981-982

[29] Boyd C.E., Water quality management of pond fish culture, Elsevier, Amsterdam, The Netherlands, 1982

[30] Garg S.K., Bhatnagar A., Effect of varying closes of organic and inorganic fertilizers on plankton production and fish biomass in brackish water fish ponds, Aquac. Res., 1996, 27, 157-166

[31] Chughtai M.I., Mahmood K., Semi-intensive carp culture in saline water-logged area: A multi-location study in Shorkot (district Jhang), Pakistan, Pak. J. Zool., 2012, 44, 1065-1072
[32] Boeck G., Nilsson G., Vlaeminck A., Blust R., Central monoaminergic responses to salinity and temperature rises in common carp, J. Exp. Biol., 1996, 199, 1605-1611

[33] Altinok I., Grizzle J.M., Effects of low salinities on Flavobacterium columnare infection of euryhaline and freshwater stenohaline fish, J. Fish Dis., 2001, 24, 361-367

[34] Zhou B.S., Wu R.S.S., Randall D.J., Lam P.K.S., Ip Y.K., Chew S.F., Metabolic adjustments in the common carp during prolonged hypoxia, J. Fish Biol., 2000, 57, 1160-1171

[35] Vega M., Pardo R., Barrado E., Debán L., Assessment of seasonal and polluting effects on the quality of river water by exploratory data analysis, Water Res., 1998, 32, 3581-3592

[36] Holmstrup M., Bindesbøl A.-M., Oostingh G.J., Duschl A., Scheil V., Köhler H.-R., et al., Interactions between effects of environmental chemicals and natural stressors: A review, Sci. Total Environ., 2010, 408, 3746-3762

[37] Howe G.E., Marking L.L., Bills T.D., Rach J.J., Mayer F.L., Effects of water temperature and $\mathrm{pH}$ on toxicity of terbufos, trichlorfon, 4-nitrophenol and 2,4-dinitrophenol to the amphipod Gammarus pseudolimnaeus and rainbow trout (Oncorhynchus mykiss), Environ. Toxicol. Chem., 1994, 13, 51-66

[38] Randall D.J., Tsui T.K.N., Ammonia toxicity in fish, Mar. Pollut. Bull., 2002, 45, 17-23

[39] Frances J., Nowak B.F., Allan G.L., Effects of ammonia on juvenile silver perch (Bidyanus bidyanus), Aquaculture, 2000, 183, 95-103

[40] Lease H.M., Hansen J.A., Bergman H.L., Meyer J.S., Structural changes in gills of Lost River suckers exposed to elevated $\mathrm{pH}$ and ammonia concentrations, Comp. Biochem. Phys. C, 2003, 134, 491-500

[41] Benli A.Ç.K., Köksal G., Özkul A., Sublethal ammonia exposure of Nile tilapia (Oreochromis niloticus L.): Effects on gill, liver and kidney histology, Chemosphere, 2008, 72, 1355-1358

[42] Wilkie M.P., Wood C.M., Recovery from high $\mathrm{pH}$ exposure in the rainbow trout: white muscle ammonia storage, ammonia washout, and the restoration of blood chemistry, Physiol. Zool., 1995, 379-401

[43] Wilkie M.P., Wright P.A., Iwama G.K., Wood C.M., The physiological adaptations of the Lahontan cutthroat trout (Oncorhynchus clarki henshawi) following transfer from well water to the highly alkaline waters of Pyramid Lake, Nevada ( $\mathrm{pH}$ 9.4), Physiol. Zool., 1994, 355-380

[44] Wright P.A., Iwama G.K., Wood C.M., Ammonia and urea excretion in Lahontan cutthroat trout 
(Oncorhynchus clarki henshawi) adapted to the highly alkaline Pyramid Lake (pH 9.4), J. Exp. Biol., 1993, 175, 153-172

[45] Wang Y.S., Gonzalez R.J., Patrick M.L., Grosell M., Zhang C., Feng Q., et al., Unusual physiology of scale-less carp, Gymnocypris przewalskii, in Lake Qinghai: a high altitude alkaline saline lake, Comp. Biochem. Phys. A, 2003, 134, 409-421

[46] Spencer P., Pollock R., Dubé M., Effects of unionized ammonia on histological, endocrine, and whole organism endpoints in slimy sculpin (Cottus cognatus), Aquat. Toxicol., 2008, 90, 300-309

[47] Sollid J., Nilsson G.E., Plasticity of respiratory structures - Adaptive remodeling of fish gills induced by ambient oxygen and temperature, Respir. Physiol. Neurobiol., 2006, 154, 241-251

[48] Karan V., Vitorović S., Tutundžić V., Poleksić V., Functional enzymes activity and gill histology of carp after copper sulfate exposure and recovery, Ecotoxicol. Environ. Saf., 1998, 40, 49-55

[49] Nilsson G.E., Gill remodeling in fish - a new fashion or an ancient secret?, J. Exp. Biol., 2007, 210, 2403-2409

[50] Poleksić V., Mitrović-Tutundžić V., Fish gills as a monitor of sublethal and chronic effects of pollution, In: Muller R., Lloyd R. (Eds.), Sublethal and chronic toxic effects of pollutants on freshwater fish, Blackwell Scientific Publications Ltd., Oxford, 1994
[51] Fernandes M.N., Mazon A.F., Environmental pollution and fish gill morphology, In: Val L., Kapoor B.G. (Eds.), Fish Adaptations, Science Publishers, Enfield, 2003

[52] Mallatt J., Fish gill structural changes induced by toxicants and other irritants: a statistical review, Can. J. Fish. Aquat. Sci., 1985, 42, 630-648

[53] Booth J.H., The effects of oxygen supply, epinephrine, and acetylcholine on the distribution of blood flow in trout gills, J. Exp. Biol., 1979, 83, 31-39

[54] Schmidt H., Bernet D., Wahli T., Meier W., Burkhardt-Holm P., Active biomonitoring with brown trout and rainbow trout in diluted sewage plant effluents, J. Fish Biol., 1999, 54, 585-596

[55] Koponen K., Myers M.S., Ritola O., Huuskonen S.E., Lindström-Seppä P., Histopathology of feral fish from a PCB-contaminated freshwater lake, AMBIO, 2001, 30, 122-126

[56] Reite O.B., Mast cells/eosinophilic granule cells of teleostean fish: a review focusing on staining properties and functional responses, Fish Shellfish Immunol., 1998, 8, 489-513

[57] Silva A.G., Martinez C.B.R., Morphological changes in the kidney of a fish living in an urban stream, Environ. Toxicol. Pharmacol., 2007, 23, 185-192

[58] Reimschuessel R., A fish model of renal regeneration and development, ILAR J., 2001, 42, 285-291 